\title{
Advertising and Its Effects on Consumer Behaviour in Kathmandu Valley
}

\author{
Rajeswor Neupane, M.Phil. \\ Associate Professor \\ Nepal Commerce Campus, Faculty of Management, T.U.
}

\begin{abstract}
Nowadays, advertisement is considered as one of the most message medium to influence buying habit of the consumer. This study aims to answer the questions that whether the demographic background of ultimate consumer i.e. age, gender, education and occupation has a varying effect on the media preference due to advertisements. The sample of 115 questionnaire were distributed and out of these 110 responses recorded and compared. The result indicated that respondents like preferred $T V$ advertisements have been found more popular as compared to Radio, Print and other media.
\end{abstract}

Keyword: Advertisement, Consumer behavior, Newspaper/Magazine, Television, Radio

\section{Introduction}

Advertisement refers to all the activities involved in presenting to a group, a non-personal oral or visual, openly sponsored message regarding a product, service idea or organization is disseminated through one or more media and is paid for by an identified sponsor. Advertising consists of all the activities involved in presenting to an audience, a non-personal, sponsor identified paid for message about a product or organization. (Stanton, et., al., 1994). 'Advertising is any paid form of non-personal presentation and promotion of ideas, goods or services by an identified sponsor (Kotler, 2006).

An advertisement is an announcement to the public of product, service or idea through a medium to which the public has access. The medium may be print (such as newspapers, banner and hoardings), electronics (radio, television, cable phone), or any other. An advertisement is usually paid for by an advertiser at fixed rate or negotiated with the media. It is a form of persuasive communication with the public. The communication is usually one sided, in one direction from the advertiser and to the public.

Advertising is the most visible marketing tools which seeks to transmit an effective message from the marketer to a group of individuals. The marketer pays for sponsoring the advertising, unlike salesmanship which interacts with a buyer face to face, is non-personal. It is directed at a mass audience; and not an individual, as in personal selling.

Advertising aims at drawing attention to a product or service. It seeks to create an awareness about the existence of advertised product or services. It passes on the information about the product and service in such a way that interest is created in the mind of the prospective customer about the product or service.

Advertising is the main tool of informing, convincing, influencing and persuading to the targeted segment and plays significant role on brand choice of consumer products. The advertiser needs comprehension of psychology. The effective advertising needs to be familiar with certain effects that lead to certain response. Advertising is a method of communication, which is one of the most important aspects of human behaviour.

Advertising is a major form of promotion in international as well as domestic marketing. People 
generally buy a product only after knowing about it. That is why: advertising plays a vital role in marketing especially in purchasing and providing information to a large number of scattered masses in different regions of the country. Advertising as a tool of mass selling is an indispensable medium. It can bring the message to millions of people at the same time, while it is not possible in the personal selling, store display etc.

Today business organization, social organization, political organization and government and nongovernment organization are also using advertising as a major tool promoting and presenting goods and services as well as political candidates for votes.

\section{Literature Review}

Advertising is micro-managerial function of any organization to send the information to other members of the society he added that it is a macro concept representing the entire advertising industry and is an institution (Sontakki, 1999).

Television has become a very effective media and the best possible media for mass communication which is being extensively used for business purpose, such as to communicate to the mass through the advertisement. Television has a significant role to play in the field of business as media for advertising. It is observed that advertising in newspaper transmitted through television is found to be most effective. It is due to the impact made by both audio and video and its wide coverage. The TV commercial is generally considered the most effective mass-market advertising format and this is reflected by the high prices TV networks charge for commercial airtime during popular TV events.

However, the effectiveness of the advertising depends upon many things but mostly it depends upon the popularity and coverage of the channel it is being transmitted through. Hence, it should of great concern to the advertisers that the channel through which their products are advertised has a wide coverage area and is popular among the viewers. This bolds true for the Nepali channels as well. Nepali channels cannot afford to be indifferent to this fact as its main source of revenue comes from the transmission of the advertisements. In the present context of intense competition and invasion of Nepali channels by private and foreign channels, the Nepali channels have to face a lot of challenges and compete with more than 80 channels to maintain its viewership. While the viewers have more choices, the Nepalese channels have more competition. Still, with the changing time and internal competition with a rise of new private channels, they have now started to change with the change in time. The transmission period and time have now been increased and various new and better programs are being transmitted regularly.

Niazi and Hunjra (2012) defined that advertising is a way of communication to convince an audience for taking purchase decision about a product or service and delivering information to viewers. This paper examines the relationship between environmental response and emotional response which are independent variables with dependent variable i.e. consumer buying behavior.

Dhaliwal (2016) explained that advertisement plays an important role in modern era as it shapes the attitudes and perceptions of individuals and society which strikingly influences the customer buying behaviour. Any business can get on the road of success when it attracts and retains the consumers with profit and this goal is achieved when company builds a strong consumer perception for its product or service. All the big guns have made significant attempts to ensure quality advertisement and fabrication of strong consumer perception through suitable ways that positively affects the consumer buying behavior because people get knowledge about product through advertisement and other promotional tools and develop perception through company's activities and his previous experience with that company and past purchase accordingly.

Shrestha (2019) revealed that advertisement is any paid form of non-personal presentation and promotion of ideas, goods or services by an identified sponsor via print media (newspaper and magazines), broad cast media (radio, and television) network media (telephone, cable, satellite, wireless), electronic media (audiotape, videotape, web-page)and display media (bill board, signs, poster). 
Nowadays Nepali market is changing from seller market to buyer market. Nepali marketers are using advertising as a tool to inform people about products and persuade them to purchase their brands. Nepali marketers has been using print media, electronic media and display media. Within print media. Due to this reason the study is designed to test the impact of advertisement on consumers' preference as a means of advertising. Therefore the main objective of this paper is to compare the effective medium of advertisement among newspaper, television, radio and other display media in Kathmandu valley.

\section{Conceptual Framework}

\section{Figure 1}

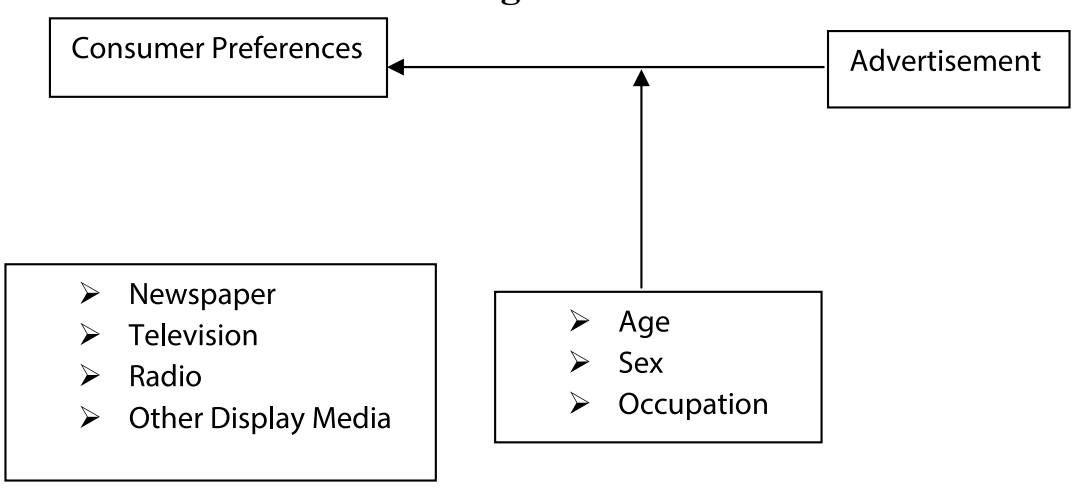

\section{Materials and Methods}

The study had adopted descriptive and analytical research design. Population of the study are people of Kathmandu valley. The data has been collected from 110 respondents from Kathmandu valley, based on purposive sampling method. Semi structured questionnaires has been framed that contained 25 questions which has been asked to consumers of different age groups, gender, education and occupation using convenience sampling from urban and suburban area of Kathmandu valley. To test the preferences of advertisement media percentage analysis was carried out with the help Ms excel which revealed relationship between advertisement media and consumer buying behavior. The data were presented in table form categorized under age, gender and occupation. 115 questions were distributed to sample respondents and 100 responses were usable ones.

\section{Result and Discussion}

Table 1: Age Wise Persuasion of Advertisement Media

\begin{tabular}{ccccccccccc}
\hline \multirow{2}{*}{ Medium } & \multicolumn{2}{c}{$15-25$} & \multicolumn{2}{c}{$26-35$} & \multicolumn{2}{c}{$36-45$} & \multicolumn{2}{c}{ Above 45} & \multicolumn{2}{c}{ Total } \\
& No & $\%$ & No & $\%$ & No & $\%$ & No & $\%$ & No. & $\%$ \\
\hline Newspaper/Magazines & 3 & 9 & 5 & 12 & 3 & 19 & 1 & 5 & 12 & 10.91 \\
Radio & - & - & 3 & 8 & 3 & 19 & 1 & 5 & 7 & 6.36 \\
Television & 28 & 82 & 29 & 72 & 10 & 62 & 8 & 40 & 75 & 68.18 \\
Other & 3 & 9 & 3 & 8 & - & - & 10 & 50 & 16 & 14.55 \\
Total & 34 & 100 & 40 & 100 & 16 & 100 & 20 & 100 & 110 & 100 \\
\hline
\end{tabular}

Source: Field Survey 2018

The above table, categorized under $15-25$ age group, $9 \%$ choose newspaper/magazine, $82 \%$ choose television and $9 \%$ preferred other medium of advertisement (hoarding board, posters, pamphlets etc). Under 26-35 age group, $12 \%$ choose newspaper/magazines, $8 \%$ Radio, $72 \%$ television and remaining $8 \%$ other medium of advertisement (hoarding boards, posters, pamphlets et\} Under 36-45 age group, 19\% choose 
newspaper/magazines, $19 \%$ choose Radio and $62 \%$ choose television, likewise, under age group of above $45,5 \%$ choose newspaper/magazines, $5 \%$ also choose radio, $40 \%$ choose television and $50 \%$ choose other media. The response under above 45 age group consider highest percentage of media selection is other media.

However, while comparing the above table clearly shows that a large percentage of respondents consider television as the most persuasive medium of advertisement. Under all the age group, it can be concluded that the most persuasive medium of advertisement is television.

Table 2 : Gender wise Persuasion of Advertisement Media

\begin{tabular}{ccccccc}
\hline \multirow{2}{*}{ Medium } & \multicolumn{2}{c}{ Male } & \multicolumn{2}{c}{ Female } & \multicolumn{2}{c}{ Total } \\
& No & $\%$ & No & $\%$ & No & $\%$ \\
\hline Newspaper/Magazines & 8 & 12 & 4 & $\mathbf{1 2}$ & $\mathbf{1 2}$ & $\mathbf{1 0 . 9 2}$ \\
Radio & 4 & 6 & 3 & $\mathbf{9}$ & $\mathbf{7}$ & $\mathbf{6 . 3 6}$ \\
Television & 51 & 76 & 24 & $\mathbf{7 3}$ & $\mathbf{7 5}$ & $\mathbf{6 8 . 1 8}$ \\
Other & 4 & 6 & 12 & $\mathbf{6}$ & $\mathbf{1 6}$ & $\mathbf{1 4 . 5 4}$ \\
Total & 67 & 100 & 43 & 100 & 110 & 100 \\
\hline
\end{tabular}

Source: Field Survey 2018

The above table have shown that while analyzing the gender group out of 67 males $12 \%$ selected newspaper/magazines, $6 \%$ radio, $76 \%$ television and $6 \%$ other means of advertisement. Among the 33 sample female respondents $12 \%$ selected newspaper/magazines, $9 \%$ radio, $73 \%$ television and $6 \%$ other means of advertisement. While the total result under gender categories shows that television is the most persuasive medium to attract the customer. It shows that television advertisement has its effects on both male and female viewers.

Table 3 : Education wise Persuasion on Advertisement Media

\begin{tabular}{|c|c|c|c|c|c|c|c|c|c|c|c|c|c|c|}
\hline \multirow[t]{2}{*}{ Medium } & \multicolumn{2}{|c|}{$\begin{array}{l}\text { Under } \\
\text { SLC }\end{array}$} & \multicolumn{2}{|c|}{ SLC } & \multicolumn{2}{|c|}{ Intermediate } & \multicolumn{2}{|c|}{ Graduate } & \multicolumn{2}{|c|}{$\begin{array}{c}\text { Post } \\
\text { Graduate }\end{array}$} & \multicolumn{2}{|c|}{ Other } & \multicolumn{2}{|c|}{ Total } \\
\hline & No & $\%$ & No & $\%$ & No & $\%$ & No & $\%$ & No & $\%$ & No & $\%$ & No & $\%$ \\
\hline $\begin{array}{c}\text { Newspaper/ } \\
\text { Magazines }\end{array}$ & - & - & 1 & 8 & 4 & 14 & 6 & 16 & 1 & 5 & - & - & 12 & 10.92 \\
\hline Radio & 1 & 10 & 1 & 8 & 2 & 7 & 2 & 5 & 1 & 5 & - & - & 7 & 6.36 \\
\hline Television & 9 & 90 & 10 & 84 & 20 & 72 & 27 & 71 & 16 & 85 & 3 & 100 & 85 & 77.27 \\
\hline Other & - & - & - & - & 2 & 7 & 3 & 8 & 1 & 5 & - & - & 6 & 5.45 \\
\hline Total & 10 & 100 & 12 & 100 & 28 & 100 & 38 & 100 & 19 & 100 & 3 & 100 & 110 & 100 \\
\hline
\end{tabular}

Source: Field Survey, 2018

The above table, categorized under education shows that for under SLC level, $10 \%$ selected radio and $90 \%$ television. For SLC level, $8 \%$ selected newspaper/magazines, $8 \%$ selected radio and $84 \%$ selected television. Under intermediated group, 14\% selected newspaper/magazines, 7\% selected radio, 72\% selected television and 7\% as other medium of advertisement (hoarding boards, posters, pamphlets etc). Under graduate level, $16 \%$ selected newspaper/magazines, $5 \%$ radio, $71 \%$ television, and $8 \%$ as other (hoarding boards, posters, pamphlets etc). Under post graduate level, 5\% selected newspaper/magazines, 
Vol. 4, No. 1

$5 \%$ selected radio, $85 \%$ television, and $5 \%$ others (hoarding boards, posters, pamphlets etc). For the other level, $100 \%$ selected television as the most persuasive medium of advertisement.

In the education category, most respondents considered television as the most persuasive medium of advertisement. The highest percentage was the other level of education who considered television as the most persuasive medium of advertisement.

Table 4 : Occupation wise Persuasion on Advertisement Media

\begin{tabular}{|c|c|c|c|c|c|c|c|c|c|c|c|c|}
\hline \multirow[t]{2}{*}{ Medium } & \multicolumn{2}{|c|}{ Student } & \multicolumn{2}{|c|}{ House Wife } & \multicolumn{2}{|c|}{$\begin{array}{l}\text { Service } \\
\text { Holder }\end{array}$} & \multicolumn{2}{|c|}{$\begin{array}{c}\text { Business } \\
\text { Man }\end{array}$} & \multicolumn{2}{|c|}{ Other } & \multicolumn{2}{|c|}{ Total } \\
\hline & No & $\%$ & No & $\%$ & No & $\%$ & No & $\%$ & No & $\%$ & No & $\%$ \\
\hline $\begin{array}{l}\text { Newspaper/ } \\
\text { Magazines }\end{array}$ & 3 & 8 & 1 & 9 & 7 & 20 & 1 & 5 & - & - & 12 & 10.92 \\
\hline Radio & - & - & 2 & 18 & 3 & 8 & 1 & 5 & 1 & 14 & 7 & $6 . .36$ \\
\hline Television & 31 & 82 & 8 & 73 & 23 & 66 & 7 & 37 & 6 & 86 & 75 & 68.18 \\
\hline Other & 4 & 10 & - & - & 2 & 6 & 10 & 53 & - & - & 16 & 14.54 \\
\hline Total & 38 & 100 & 11 & 100 & 35 & 100 & 19 & 100 & 7 & 100 & 110 & 100 \\
\hline
\end{tabular}

Source: Field Survey 2018

The above table categorized under occupation shows that for students group. $8 \%$ of the respondents selected newspaper/magazine, $82 \%$ selected television, and remaining 10\% selected other (hoarding boards, posters, pamphlets etc). Under housewife, $9 \%$ of the respondents selected newspaper/magazine, $18 \%$ selected radio, $73 \%$ television. Under Service Holders group, 20\% selected newspaper/magazine, $8 \%$ radio, $66 \%$ television and remaining $6 \%$ selected others (hoarding boards, posters, pamphlets etc). Under Businessman, 5\% selected newspaper/magazines, 5\% radio, and 37\% selected television and remaining $53 \%$ other media. Under others group, $14 \%$ selected radio while the rest $86 \%$ selected television as the most persuasive medium of advertisement. In the business person group the highest percentage of media selection is other. However, out of 110 total respondents $10.92 \%$ choose newspaper, 6.36 choose radio, and 68.18 choose television while the remaining $14.54 \%$ choose other media of advertisement. This clearly indicate television is the most persuasive medium of advertisement.

It has its effect on the entire category under age, gender, education and occupation. Hence, we can consider television to be a persuasive medium of advertisement.

\section{Conclusion}

On the basis of the presentation and analysis of above mentioned data, the conclusions were drawn. According to the survey, large percentage of respondents specified television as the most persuasive medium of advertisement. This without doubt indicates television to be the most preferred medium of advertisement. Though the four types of media spread awareness but television advertisement plays a vital role in buying behavior of consumer. This is because advertisement of TV is more glamorous, and more specialized it provides scientific synchronization of sound, color, light, and other feature that that no other medium does it. This indicate that television is the popular medium. This study has opened the ground for the further study. This study can also be extended with additional variables such as quality price time, reliability and so on.

\section{Implications}

This article is useful for marketing executives, advertising agencies, academician, and business 
practioners. The contained of the report facilitates students to add their references for assign topics specially marketing and management. Similarly, consumers and business houses can also receive a lot of information in their respective fields.

\section{References}

Dhaliwal, A. (2016). Effect of Advertisement on Consumer Buying Behavior, International Journal of scientific research and management (IJSRM), |Volume 4, Issue, 09

Niazi \& Hunjra (2012). Effective Advertising and its Influence on Consumer Buying Behavior (August 16, 2012). Information Management and Business Review, Vol. 4, No. 3, pp. 114-119

Kotler, P. (2006). Principles of Marketing, eleventh edition, New Delhi, Prentice Hall of India.

Neupane, R. (2018). Packaging and Its Role on Consumers' Perception at Point of Purchase in Kathmandu Valley, International Journal of Science and Business, 2(4), 725-737.

Neupane, R. et all. (2074), Fundamentals of Marketing, Osis Publication (P) Ltd. 2074, revised edition

Neupane, R. (2019). Relationship Marketing and Customer Loyalty of Nepali Commercial Banks, International Journal of Management Studies, Vol.-VI, Special Issue 2,

Santoki, C.N. (1999). Advertising, Kalyani Publishers, India

Shrestha, P. (2019) Marketing Management: text and cases, Kriti Publication, p. 307

Stanton, J. et al. (1994). Fundamentals of Marketing, McGraw-Hill 